\title{
Phylogeny within the Anacardiaceae predicts host range of potential biological control agents of Brazilian peppertree
}

\author{
G. S. Wheeler ${ }^{1 *}$, and P. T. Madeira ${ }^{1}$ \\ ${ }^{1}$ Invasive Plant Research Laboratory, USDA-ARS, 3225 College Avenue, Ft. Lauderdale, Florida, \\ 33314, USA
}

*Corresponding author greg.wheeler@ars.usda.gov

\section{Abstract}

Predicting the host range of a biological control agent prior to release is one of the most important steps in the development of new agents. Knowing which species are most at risk of this non-target damage improves the predictability of these tests. To predict safety, the potential agent is exposed to a subset of the entire flora that represents valued native, agricultural and ornamental plant species. The list of plants includes those species that are the closest relatives to the target weed. To identify these species, molecular phylogenies can be useful tools that potentially identify the most vulnerable plant species. While conducting biological control research of the invasive weed Brazilian peppertree, Schinus terebinthifolia, we conducted nuclear ITS1 and chloroplast trnL-F analysis of agricultural, commercial and native plants that are related to the weed. The results of this analysis support recent phylogenetic studies that have established two subfamily clades of the Anacardiaceae, the Anacardioideae and the Spondioideae. Moreover, our results indicate that species of concern from the genera Cotinus, Lithrea, Pistacia, Rhus, Toxicodendron, and Schinus, group together in the Anacardioideae, whereas the Spondias species, group in the Spondioideae subfamily clade. Further, the closest relatives to the target weed, those species most at risk of non-target damage by biological control agents include members of the Schinus and Lithrea genera. A review of the host testing results of 17 potential biological control candidates indicated that three of these species show a significant phylogenetic signal in their host range. These three species, the sawfly, Heteroperreyia hubrichi, the foliar gall inducing psyllid Calophya latiforceps, and the thrips Pseudophilothrips ichini have been recommended for release by 
USDA/APHIS/TAG. The remaining herbivore species do not sufficiently restrict their host range to the closest relatives but feed generally throughout the Anacardiaceae family. For members of this plant family our results indicate that a significant phylogenetic signal with host range was found for herbivore species identified for biological control of Brazilian peppertree. These results indicate that the testing of species with high phylogenetic distances, such as safeguard species, could be minimized without loss of host range predictability of potential biological control agents.

Keywords: phylogenetic distance, Schinus terebinthifolia, Anacardiaceae, molecular phylogeny, host specificity, Diet breadth, Dietary specialization, Host specialists, Host range specialization 


\section{Introduction}

Dietary specialization, where herbivores are restricted to plant species within a single taxon, is a common condition in tropical insects (Novotny and Basset, 2005; Novotny et al., 2002). This narrow host specificity is exploited in classical biological control by developing specialist herbivores to control invasive weeds. A major goal in the development of a biological control program is predicting the plant species that might serve as hosts to a new agent. Due to concerns for safety to valued native and economic plants, rigorous host specificity testing is conducted prior to consideration for release (McEvoy, 1996; Schaffner, 2001). As the testing of the entire flora of an invaded area is not possible, a subset is tested where the most vulnerable species are given priority. Determining this high priority list of species to include in the testing protocol is a critical step in this process.

Host range test plant lists have been traditionally compiled with the centrifugal phylogenetic approach which was based on morphological similarity among taxa (Wapshere, 1974). This morphological-based approach has been challenged and modified by advances in molecular phylogeny (Kelch and McClay, 2004). The species most closely related phylogenetically to the weed share similar traits and thus deserve close scrutiny as they are thought to be most at risk from the non-target effects of biological control (Agrawal, 2007; Futuyma and Agrawal, 2009; Pearse and Hipp, 2009). With this molecular approach, the testing of safeguard species, those that have important economic or environmental significance but are from distant phylogenetic relationships, become irrelevant as their analysis does not assist in predictions of host range (Briese, 2005; Briese and Walker, 2002). To prioritize testing of the close relatives, modern molecular phylogenies are needed that include the relevant species cooccurring in the weed's invaded range (Hinz et al., 2008).

For insect herbivores developed for biological control of weeds, molecular phylogenies assist in the prioritization and selection of plant species for testing (Briese, 1996; Briese and Walker, 2008). Knowing which valued plant species might be most vulnerable to non-target damage has obvious advantages when allocating resources during the host testing phase of a project. The strength of this phylogenetic signal can accurately predict host range of both plant pathogens and herbivores (Gilbert et al., 2015; Gilbert and Webb, 2007). To examine host range 
in terms of phylogeny, phylogenetic distances have been calculated among members of different potential host plants (Forister et al., 2015; Hinz et al., 2008; Novotny et al., 2006). Calculating the phylogenetic distance is a valuable method during pre-release screening, especially for plants below the family taxon, when evaluating the host range of potential agents for the biological control of weeds.

Brazilian peppertree, Schinus terebinthifolia Raddi, is a weed of agricultural and environmental concern of Florida and Hawaii, USA. This species is assigned to the Anacardiaceae family in the order Sapindales. Recent molecular analysis indicated that the Anacardiaceae family consists of two subfamilies, the Anacardioideae and the Spondioideae (Pell et al., 2011). Members of the Anacardioideae subfamily include the agricultural mango (Mangifera indica L.), pistachio (Pistacia spp.), and cashew (Anacardium occidentale L.) species (Mitchell and Mori, 1987; Pell et al., 2011). Additionally, this subfamily includes several native North American species, the smoketrees (Cotinus spp), poisonwood (Metopium), the sumacs (e.g., Rhus spp.) and poison ivy (Toxicodendron spp.). The only species in our range to be assigned to the Spondioideae subfamily include the species of the Caribbean mombin (Spondias spp.). Modern phylogenies have been compiled for several genera of the Anacardiaceae, including Pistacia (Al Saghir, 2010), Rhus (Yi et al., 2007), Spondias (Miller and Schaal, 2005), and Toxicodendron (Nie et al., 2009). However, the relationship among the genera of the family, e.g., which are most closely aligned with Schinus, remains uncertain (Pell, 2004). Knowledge of the relative phylogenetic proximity of these genera to Schinus could assist in the prioritization of test plants during the pre-release testing process.

The host range of several potential biological control agents of S. terebinthifolia examined during the past 50 years was recently summarized (Wheeler et al., 2016b). The results of host range testing indicated that the majority of potential agents collected on $S$. terebinthifolia in its native range, showed relatively broad specificity within the Anacardiaceae family when examined in quarantine (Wheeler et al., 2016b). However, three species, the defoliating sawfly, Heteroperreyia hubrichi Malaise (Hymenoptera: Pergidae), the foliar gall inducing psyllid Calophya latiforceps Burckhardt (Hemiptera: Calophyidae) and the thrips Pseudophilothrips ichini (Hood) (Thysanoptera: Phlaeothripidae) have demonstrated narrow 
host ranges and have been recommended for release by USDA/APHIS/TAG (Diaz et al., 2015; Medal et al., 1999; USDA/APHIS, 2016; Wheeler et al., 2016a). Here, we examine the phylogenetic distance of members of the Anacardiaceae in the native and invaded ranges of $S$. terebinthifolia generated in this study and relate these retrospectively to host range determinations of previously studied potential agents.

\section{Materials and Methods}

\subsection{Source populations of plant material}

Plant species were obtained from plant nurseries or wild populations (Supplementary Table 1). For species not available commercially, seeds were collected from wild populations in Florida, Hawaii, and Texas, USA. The South American species (e.g., Lithrea and Schinus spp.) were collected by the authors in the Brazilian states of Minas Gerais and Rio Grande do Sul. The Brazilian peppertree control plants were grown from locally collected seeds. In all cases, fresh leaf tips ( 100 mg) were collected and preserved on silica gel until analysis. Two outgroup species were included, Dodonaea viscosa Jacquin and D. elaeagnoides Rudolphi ex Ledeb. \& Alderst., (Sapindaceae) as a small amount of herbivory was found during previous testing of $D$. viscosa (Wheeler et al., 2016a) (Supplementary Table 1).

\subsection{Molecular extraction and analysis.}

DNA was extracted using the DNeasy Plant Mini kit (Qiagen Inc., Valencia, CA, USA). The nuclear ITS1 sequences (ITS1, 5.8S, and partial ITS2 sequences) were amplified and sequenced using the ITS-A, ITS-B, ITS-C and ITS-D primers) (Blattner, 1999). The PCR reaction contained 10 $\mathrm{mM}$ Tris- $\mathrm{HCl}$ (pH 9.0), $50 \mathrm{mM} \mathrm{KCl}, 1.5 \mathrm{mM} \mathrm{MgCl}_{2}, 0.1 \%$ Triton X-100, 10\% DMSO, $0.2 \mathrm{mM}$ dNTPs, $0.5 \mu \mathrm{M}$ each primer, and $0.04 \mathrm{U} / \mu$ l EconoTaq polymerase (Lucigen Corp., Middleton, WI, USA). The $t r n L-F$ (chloroplast $t r n L$ intron and $t r n L-F$ intergenic spacer) were amplified and sequenced using the $\operatorname{trnL}-\mathrm{C}, \operatorname{trnL}-\mathrm{D}, \operatorname{trn} L-E$ and $\operatorname{trn} L-\mathrm{F}$ primers of Taberlet et al. (1991). Plastid reaction mixtures contained $10 \mathrm{mM}$ Tris- $\mathrm{HCl}(\mathrm{pH} 9.0), 50 \mathrm{mM} \mathrm{KCl}, 1.5 \mathrm{mM} \mathrm{MgCl}_{2}, 0.1 \%$ Triton X100, $0.5 \mathrm{mM}$ Betaine, 0.001\% BSA, $0.2 \mathrm{mM}$ dNTPs, $0.5 \mu \mathrm{M}$ each primer, and $0.06 \mathrm{U} / \mu \mathrm{l}$ EconoTaq polymerase. The amplifications were carried out on a PTC-100 thermocycler (MJ 
Research, Inc. Waltham, MA, USA). PCR annealing temperatures were $56^{\circ} \mathrm{C}$ for $\operatorname{trnL}-F$ and $58^{\circ} \mathrm{C}$ for ITS1. PCR products were visualized using 1.5\% agarose gels stained with ethidium bromide then were cleaned using DNA Clean \& Concentrator (Zymo Research, Orange, CA, USA). Cycle sequencing was performed by Eurofins MWG Operon (Louisville, KY, USA) using BigDye terminator technology (Life Technologies, Carlsbad, CA, USA).

Trace files were compiled and viewed using SEQUENCER 4.1.4 (Gene Codes Corporation, Ann Arbor, MI, USA). Reference sequences were downloaded from the NCBI "Taxonomy" window or using BLASTn to find similar sequences. Sequences were aligned at one of the several MCoffee Web servers [http://tcoffee.crg.cat/]. MCoffee (Moretti et al., 2007; Wallace et al., 2006) uses an algorithm which aligns DNA by combining the output of multiple popular aligners (e.g., Clustal, Mafft, Probcons, Muscle) and produced a 761 b.p. alignment for the ITS1 sequences and an 1181 b.p. alignment for trnL-F. The ITS1 sequence contained gap coding (-) in $13.6 \%$ of individual sequence positions while trnL-F contained them in $22.9 \%$ of positions. Following MCoffee, a Transitive Consistency Score (TCS) was generated at the same server. TCS (Chang et al., 2014) is an alignment evaluation score which identifies the alignment positions most likely to be correct (homologous) and therefore also the most informative for estimating phylogenetic trees. This alignment allows systematic incorporation of some informative data from the regions of an alignment with gaps which otherwise might be excluded by "complete deletion". TCS produced a 643 bp alignment for the ITS1 sequences and a 924 bp alignment for trnL-F with $0.8 \%$ and $3.8 \%$ individual position gaps respectively. Wiens and Morrill (2011) indicate that, in general, including characters with missing data either increases or has minimal effect on the mean accuracy of Bayesian phylogenetics. Similarly, Dwivedi and Gadagkar (2009) show that, when the indel events (without alignment error) represent $\leq 20$ percent of the sequence length, most methods, but especially Maximum Likelihood and Bayesian methods perform well. As gaps increase, Bayesian methods outperform other methods when the gaps are treated as missing data. Clearly, following TCS, the remaining sites contain low levels of gaps and should provide information with minimal phylogenetic distortion for Bayesian analysis.

To identify the phylogenetic relatedness to the target weed, Brazilian peppertree, a 
single distance metric was sought to aid the analysis. The search for an optimum model of nucleotide substitution led us to Kakusan4 (Tanabe, 2011), a program which facilitates model selection for multigene phylogenetic analysis by allowing for different nucleotide substitution models at different loci. The data was subdivided into five components: ITS1 (251 b.p. alignment), 5.8S rRNA (162 b.p.), ITS2 (213 b.p.), TrnL intron (450 b.p.), TrnL-TrnF intergenic spacer (370.b.p.), and then run through Kakusan4. A $\chi 2$ test showed nucleotide homogeneity among all taxa. After deciding to use MrBayes for analysis, the BIC4 criterion was used to compare Nonpartitioned, Proportional, Partitioned_Equal_Mean_Rate, and Separate models. The Proportional model, which assumes that branch lengths are proportional among arbitrarily specified partitions, proved optimal. Model configuration files for MrBayes (Ronquist and Huelsenbeck, 2003) generated in Kakusan4 were: 5.8SrRNA = K80_Gammalnvariant, ITS1 = GTR Gamma, ITS2 = HKY85 Gamma, TrnL intron = GTR Gamma, TrnL-TrnF spacer = GTR Gamma. Bayesian analysis utilized MrBayes5D, an extended version of MrBayes [https://www.fifthdimension.jp/products/mrbayes5d/]. Because of model complexity and the relatively short sequence lengths, long burnin $(1,000,000)$ and ngen $(10,000,000)$ were chosen (also nchains=6) to produce higher Effective Sample Sizes (ESS). ESS values were above 200 for all parameters, including model parameters.

\subsection{Retrospective analysis of host range data}

To examine the relationship between phylogenetic distance and host range, we retrospectively analyzed testing results from previous studies. To date, at least 17 insect herbivores have been tested to determine their suitability for biological control of $S$. terebinthifolia (Table 1). These include species of Hemiptera, Thysanoptera, Coleoptera, Lepidoptera, and Hymenoptera. Of these species, three have been recommended for release as biological control agents of S. terebinthifolia due to their narrow host range (Wheeler et al., 2016b). Research showed that the sawfly, H. hubrichi had a narrow host range but was not released possibly due to concern for its potential mammalian toxicity (Dittrich et al., 2004; Hight et al., 2003; Medal et al., 1999). The leaf gall former, C. latiforceps was considered highly specific, only surviving on the target weed S. terebinthifolia (Diaz et al., 2015). The thrips, $P$. 
ichini, completed development and produced offspring only on two weedy Schinus species, S. terebinthifolia and S. molle L. (Wheeler et al., 2016a). Other species released for biological control of S. terebinthifolia in Hawaii, Crasimorpha infuscata Hodges (Lepidoptera: Gelechiidae) and Lithraeus atronotatus (Pic) (Coleoptera: Chrysomelidae) were not included here due the shortage of published host range data (Davis, 1961; Davis and Krauss, 1962; Krauss, 1962; Krauss, 1963). A third species released in Hawaii, Episimus unguiculus Clarke (Lepidoptera: Tortricidae) was later tested and these host range data are included in the analysis here.

To examine the relationship between host range and phylogenetic distance, previous published and unpublished host testing results were compiled. These data were collected while determining the host range of potential biological control agents of S. terebinthifolia in quarantine. To standardize responses of each herbivore species we divided the results when fed a non-target (e.g., percent survival, growth rates, pupal weight) by that of those fed the target weed. We used both physiological (e.g., survival) and behavioral (e.g., oviposition) relative response values, each relative to the respective $S$. terebinthifolia -fed controls. We fit these results to an exponential decay equation $y=b_{o} * \exp \left(-b_{1} x\right)$ using PROC NLIN in SAS where $y$ was the relative response (\% of control), $b_{0}$ was the $y$-intercept, $b_{1}$ was the slope coefficient

and $x$ was $\log _{10}($ distance +1$)$. To compare the relationship for species recommended for release (H. hubrichi, C. latiforceps, $P$. ichini) with those rejected due to broad host range, and to compare physiological and behavioral responses, we compared confidence limits (95\%) for the non-linear regression coefficients and graphically visualized their relationships.

\section{Results}

\subsection{Results of molecular analysis}

The results of analysis of the combined nuclear and chlorophyll DNA data indicated that two subfamily clades were discernable and separately group species to the Anacardioideae and the Spondioideae (Fig. 1). Note that species within each genus Cotinus, Lithrea Pistacia, Rhus, Schinus, Searsia, Spondias and Toxicodendron all group together in their respective assigned genera. As expected, this analysis indicated that the species most closely related to $S$. terebinthifolia include members of the Schinus and Lithrea genera. Moreover, species least 
related phylogenetically to the weed are members of the subfamily Spondioideae (e.g., Spondias spp.) and the outgroup family Sapindaceae (Fig. 1). Calculated phylogenetic distances between taxa and the weed, S. terebinthifolia indicated that the species of the genus Schinus had an average range of 0.219 to 0.306 (Table 2 ). These results also demonstrated that the closest relatives of Schinus are assigned to the genera, Cotinus, Lithrea, Pistacia, Rhus, and Toxicodendron with average ranges 0.381 to 0.633 . Within the family, the greatest distance was found between S. terebinthifolia and A. occidentale, M. indica $(0.948-1.193)$ and the species of Spondias (1.61 - 1.708) (Table 2). Phylogenetic distances for the outgroup species of Dodonaea averaged from 2.474 to 2.496 (Table 2 ).

\subsection{Analysis of retrospective host range results.}

The relative response of biological control agents recommended for field release initially declined steeply with slight increases in phylogenetic distance from the target weed, $S$. terebinthifolia (Fig. 2). In contrast to these results, those species that had unacceptable host ranges and were rejected for biological control had gradually decreasing responses to increased phylogenetic distance (Fig. 2). This steep decline in the approved agents was a function of the great reduction in relative performance in insects fed plants with greater phylogenetic distance. The slope coefficients for species recommended and rejected for field release differed significantly as indicated by the lack of overlap between their confidence intervals (95\%) (Table 3). The shape and steepness of the phylogenetic signal of the three recommended agent responses were similar. Similarly, the coefficients for behavioral data were similar to physiological results (Table 3). Moreover, the behavioral results showed herbivore responses deviated slightly from the prediction. For example, the leaf gall former $C$. latiforceps only survived (physiological data) on S. terebinthifolia, however a few eggs were laid (behavioral data) on the non-target species such as S. molle, Rhus aromatica Aiton, and Toxicodendron radicans (L.) Kuntze (Fig. 2) (Diaz et al., 2015). Physiological data varied less than behavioral data for all species. For example, although relatively specific, the sawfly, $H$. hubrichi, fed and oviposited on several species like Rhus copallina L. and Toxicodendron vernix (L.) Kuntze but in quarantine host range testing they completed development only on the target weed, Rhus 
sandwicensis A. Gray and A. occidentale (Hight et al., 2003; Medal et al., 1999).

\section{Discussion}

Risks of damage to non-target species by biological control agents may include several factors among them, phylogenetic proximity to the target weed. One of the first steps to minimize this risk is the selection of target weeds for biological control that have few or no native or economically important relatives (Pemberton, 1996). Herbivores typically feed and develop on plant species that are closely related phylogenetically (Jaenike, 1990; Pearse and Altermatt, 2013) and so, risk of non-target damage is greatest toward species that are closely related to the target weed (Pemberton, 2000; Suckling and Sforza, 2014). However, when working on weeds from families with many genera and species in the invaded range, the testing protocol must prioritize those plants that are most vulnerable to non-target damage. This prioritization is facilitated by estimation of the phylogenetic distance to the target weed.

The results of analysis of the combined nuclear ITS and chloroplast trnL-F DNA data confirm recent phylogenetic studies that have established two subfamily clades of the Anacardiaceae (Pell et al., 2011). Our results group North and South American species into the Anacardioideae and the Spondioideae. Moreover, our results indicate that species of the genera Cotinus, Lithrea Pistacia, Rhus, Toxicodendron, and Schinus are distinctly separated by phylogenetic distance from species of Spondias (Pell et al., 2011). The results indicate that the species most closely related to the target, and so, most at risk of non-target damage by biological control agents include members of the Schinus and Lithrea genera. With the exception of the ornamental S. molle that was imported from South America, the species of these genera do not occur in North America. Schinus molle occurs in California, USA where it has also naturalized in wild habitats and is considered invasive (Howard and Minnich, 1989; Nilsen and Muller, 1980).

A retrospective analysis of previous host testing results of potential biological control agents of S. terebinthifolia indicate a strong phylogenetic signal that influenced the host range of insects recommended for field release. In previous host testing of the sawfly $H$. hubrichi, the 
psyllid $C$. latiforceps and the thrips $P$. ichini were shown to have narrow host ranges. The results presented here indicate that there was a strong phylogenetic signal predicting host ranges restricted to the target weed and its closest relatives. Where responses occurred in these specialists, they were directed at the non-target species most closely related to the weed, $S$. terebinthifolia. The remaining herbivore species of potential agents that were not petitioned or not recommended for release had host ranges that were too broad for biological control. The phylogenetic signal of these rejected species was significantly different from the approved biological control agents.

Other factors, such as secondary plant chemistry, may influence host range (Agrawal, 2007; Gershenzon and Dudareva, 2007). Possibly the secondary chemistry of the taxa of Anacardiaceae accurately predict the host range of the apparent Schinus specialists (Becerra, 1997; Wahlberg, 2001; Wheeler and Schaffner, 2013). In one example, the host range of Nystalea ebalea Stoll (Lepidoptera: Notodontidae) was explained by the urushiol secondary chemistry of the members of the Anacardiaceae tested (Wheeler et al., 2014). However, neither terpenoids nor urushiol chemistry seemed to predict host range for the remaining potential agents tested. The results reported here show that, for biological control of $S$. terebinthifolia, phylogenetic distance accurately predicted host range in the potential agents tested. These results question the allocation of resources to test unrelated plant species with high phylogenetic distances. Although, the testing of safeguard species that are unrelated to the target weed is still required in the U.S.A. (Littlefield and Buckingham, 2004; USDA/APHIS, 2016), possibly results similar to those presented here on additional weed-agent systems will facilitate the modification of these requirements. 


\section{Acknowledgments}

We thank K. Dyer for technical assistance, P. Conant (retired Hawaii Dept. of Agriculture, Hilo, HI), C. Kallsen (UC, Davis, CA), L. Miller (S \& J Ranch, Pinedale, CA), T. Pernas (formerly National Park Service, Homestead, FL), J. Skiles (Langtry, TX), A. Vacek (USDA/ARS, Weslaco, TX) and R. Weaver (retired botanist DPI, Gainesville, FL) provided seeds of hard to find plant species. William Overholt (retired University of Florida, Ft Pierce FL) provided useful comments on a previous draft of this manuscript. This project was partially funded by the Florida Fish and Wildlife Conservation Commission (\#08250, TA:088), the South Florida Water Management District (\#4600001427), the USDA, ARS. 
Figure Captions:

Fig. 1. Majority rule tree from Bayesian analysis (MrBayes) of combined nuclear and chloroplast sequence data from species of the Anacardiaceae and Sapindaceae. Branch lengths are proportional to Bayesian distances. Group A consists of genera of the subfamily clade Anacardioideae, B the subfamily Spondioideae and C the (outgroup) family Sapindaceae. The numbers at each node represent posterior probabilities. Species were collected by the authors unless names are followed by an asterisk. In these species, nuclear or chloroplast sequences were obtained from GenBank (www.nbci.nlm.nih.gov). Names followed by a number represent different accessions.

Fig. 2. Response (\% of control) of different herbivore species when fed plants with a range of phylogenetic distances from the target weed Schinus terebinthifolia. The relative responses for recommended biological control agents (C. latiforceps, H. hubrichi, P. ichini) dropped precipitously when fed more distantly related plant species. Herbivores that were rejected for biological control because of broad host ranges, showed a gradual decrease in herbivore response with greater phylogenetic distance. Regression coefficients and confidence intervals are included (Table 3). 


\section{References}

Agrawal, A.A., 2007. Macroevolution of plant defense strategies. Trend. Ecol. Evol. 22, 103-109.

Al Saghir, M.G., 2010. Phylogenetic analysis of the genus Pistacia L. (Anacardiaceae) based on morphological data. Asian J. Plant Sci. 9, 28-35.

Becerra, J.X., 1997. Insects on plants: Macroevolutionary chemical trends in host use. Science 276, 253-256.

Blattner, F.R., 1999. Direct amplification of the entire ITS region from poorly preserved plant material using recombinant PCR. BioTechniques 27, 1180-1186.

Briese, D.T., 1996. Phylogeny: Can it help us to understand host choice by biological weed control agents? In: Moran, V.C., Hoffmann, J.H. (Eds.), Proceedings of the IX International Symposium on Biological Control of Weeds. University of Cape Town, Stellenbosch, South Africa, pp. 19-26.

Briese, D.T., 2005. Translating host-specificity test results into the real world: The need to harmonize the yin and yang of current testing procedures. Biol. Control 35, 208-214.

Briese, D.T., Walker, A., 2002. A new perspective on the selection of test plants for evaluating the host-specificity of weed biological control agents: the case of Deuterocampta quadrijuga, a potential insect control agent of Heliotropium amplexicaule. Biol. Control $25,273-287$.

Briese, D.T., Walker, A., 2008. Choosing the right plants to test: The host-specificity of Longitarsus sp. (Coleoptera: Chrysomelidae) a potential biological control agent of Heliotropium amplexicaule. Biol. Control 44, 271-285.

Chang, J.-M., Tommaso, P.D., Notredame, C., 2014. TCS: A new multiple sequence alignment reliability measure to estimate alignment accuracy and improve phylogenetic tree reconstruction. Mol. Biol. Evol. 31, 1625-1637.

Davis, C.J., 1961. Recent introductions for biological control in Hawaii - VI. Proc. Hawaiian Entomol. Soc. 17, 389-393.

Davis, C.J., Krauss, N.L., 1962. Recent introductions for biological control in Hawaii - VII. Proc. Hawaiian Entomol. Soc. 18, 125-129. 
Diaz, R., Manrique, V., Munyaneza, J.E., Sengoda, V.G., Adkins, S., Hendricks, K., Roberts, P.D., Overholt, W.A., 2015. Host specificity testing and examination for plant pathogens reveals that the gall-inducing psyllid Calophya latiforceps is safe to release for biological control of Brazilian peppertree. Entomol. Exp. Appl. 154, 1-14.

Dittrich, R.L., Macedo, J.H.P., Cuda, J., Biondo, A.W., . 2004. Brazilian peppertree sawfly larvae toxicity in bovines. Vet. Clin. Pathol. 33, 191.

Dwivedi, B., Gadagkar, S.R., 2009. Phylogenetic inference under varying proportions of indelinduced alignment gaps. BMC Evol. Biol. 9, 211.

Forister, M.L., Novotny, V., Panorska, A.K., Baje, L., Basset, Y., Butterill, P.T., Cizek, L., Coley, P.D., Dem, F., Diniz, I.R., Drozd, P., Fox, M., Glassmire, A.E., Hazen, R., Hrcek, J., Jahner, J.P., Kaman, O., Kozubowski, T.J., Kursar, T.A., Lewis, O.T., Lill, J., Marquis, R.J., Miller, S.E., Morais, H.C., Murakami, M., Nickel, H., Nicholas, P., Ricklefs, R.E., Singer, M.S., Smilanich, A.M., Stireman, J.O., Villamarin-Cortez, S., Vodka, S., Volf, M., Wagner, D.L., Walla, T., Weiblen, G.D., Dyer, L.A., 2015. The global distribution of diet breadth in insect herbivores. Proc. Nat. Acad. Sci. 112, 442-447.

Futuyma, D.J., Agrawal, A.A., 2009. Macroevolution and the biological diversity of plants and herbivores. Proc. Nat. Acad. Sci. 106, 18054-18061.

Gershenzon, J., Dudareva, N., 2007. The function of terpene natural products in the natural world. Nat. Chem. Biol. 3, 408-414.

Gilbert, G.S., Briggs, H.M., Magarey, R., 2015. The impact of plant enemies shows a phylogenetic signal. PLOS ONE 10.

Gilbert, G.S., Webb, C.O., 2007. Phylogenetic signal in plant pathogen-host range. Proc. Nat. Acad. Sci. 104, 4979-4983.

Hight, S.D., Horiuchi, I., Vitorino, M.D., Wikler, C., Pedrosa-Macedo, J.H., 2003. Biology, host specificity tests, and risk assessment of the sawfly Heteroperreyia hubrichi, a potential biological control agent of Schinus terebinthifolius in Hawaii. BioControl 48, 461-476.

Hinz, H.L., Schwarzlander, M., Gaskin, J.F., 2008. Does phylogeny explain the host-choice behaviour of potential biological control agents for Brassicaceae weeds? In: Julien, M.H., Sforza, R., Bon, M.C., Evans, H.C., Hatcher, P.E., Hinz, H.L., Rector, B.G. (Eds.). CAB 
International pp. 418-425.

Howard, L.F., Minnich, R.A., 1989. The introduction and naturalization of Schinus molle (pepper tree) in Riverside, California. Landscape Urban Plan. 18, 77-95.

Jaenike, J., 1990. Host specialization in phytophagous insects. Ann. Rev. Ecol. Syst. 21, 243-273.

Kelch, D.G., McClay, A.S., 2004. Putting the phylogeny into the centrifugal phylogenetic method. In: Cullen, J.M., Briese, D.T., Kriticos.D.J., Lonsdale, W.M., Morin, L., Scott, J.K. (Eds.), Proceedings of the XI International Symposium on Biological Control of Weeds. CSIRO Entomology, Canberra, Australia, pp. 287-291.

Krauss, N.L., 1962. Biological control investigations on insect, snail and weed pests in tropical America, 1961. Proc. Hawaiian Entomol. Soc. 18, 131-133.

Krauss, N.L., 1963. Biological control investigations on Christmas berry (Schinus terebinthifolius) and Emex (Emex spp.). Proc. Hawaiian Entomol. Soc. 18, 281-287.

Littlefield, J.L., Buckingham, G.R., 2004. Host specificity testing of bioloigcal control agents of weeds. In: Coombs, E.M., Clark, J.K., Piper, G.L., Cofrancesco, A.F. (Eds.), Biological Control of Invasive Plants in the United States. Oregon State University Press, Corvallis, OR, pp. 32-37.

McEvoy, P.B., 1996. Host specificity and biological pest control - How well is research on host specificity addressing the potential risks of biological control. Bioscience 46, 401-405.

Medal, J.C., Vitorino, M.D., Habeck, D.H., Gillmore, J.L., Pedrosa, J.H., De Sousa, L.P., 1999. Host specificity of Heteroperreyia hubrichi Malaise (Hymenoptera: Pergidae), a potential biological control agent of Brazilian peppertree (Schinus terebinthifolius). Biol. Control $14,60-65$.

Miller, A., Schaal, B., 2005. Domestication of a Mesoamerican cultivated fruit tree, Spondias purpurea. Proc. Nat. Acad. Sci. 102, 12801-12806.

Mitchell, J.D., Mori, S.A., 1987. The cashew and it relatives (Anacardium: Anacardiaceae). Mem. New York Bot. Gard. 42, 1-76.

Moretti, S., Armougom, F., Wallace, I.M., Higgins, D.G., Jongeneel, C.V., Notredame, C., 2007. The M-Coffee web server: a meta-method for computing multiple sequence alignments by combining alternative alignment methods. Nucleic Acids Res. 35, W645-W648. 
Nie, Z.L., Sun, H., Meng, Y., Wen, J., 2009. Phylogenetic analysis of Toxicodendron

(Anacardiaceae) and its biogeographic implications on the evolution of north temperate and tropical intercontinental disjunctions. J. Syst. Evol. 47, 416-430.

Nilsen, E.T., Muller, W.H., 1980. A comparison of the relative naturalization ability of two Schinus species in southern California. I. Seed germinations. J. Torrey Bot. Soc. 107, 5156.

Novotny, V., Basset, Y., 2005. Host specificity of insect herbivores in tropical forests. Proc. R. Soc. B 272, 1083-1090.

Novotny, V., Basset, Y., Miller, S.E., Weiblen, G.D., Bremer, B., Cizek, L., Drozd, P., 2002. Low host specificity of herbivorous insects in a tropical forest. Nature $416,841-844$.

Novotny, V., Drozd, P., Miller, S.E., Kulfan, M., Janda, M., Basset, Y., Weiblen, G.D., 2006. Why are there so many species of herbivorous insects in tropical rainforests? Science 313, 1115-1118.

Pearse, I.S., Altermatt, F., 2013. Predicting novel trophic interactions in a non-native world. Ecol. Let. 16, 1088-1094.

Pearse, I.S., Hipp, A.L., 2009. Phylogenetic and trait similarity to a native species predict herbivory on non-native oaks. Proc. Nat. Acad. Sci. 106, 18097-18402.

Pell, S.K., 2004. Molecular systematics of the cashew family (Anacardiaceae). Louisiana State University, pp. 1-173.

Pell, S.K., Mitchell, J.D., Miller, A.J., Lobova, T.A., 2011. Anacardiaceae. In: Kubitzki, K. (Ed.), The Families and Genera of Vascular Plants; Flowering Plants Eudicots Sapindales, Cucurbitales, Myrtaceae. Springer-Verlag, New York, pp. 7-50.

Pemberton, R.W., 1996. The potential of biological control for suppression of invasive weeds in southern environments. Castanea 61, 313-319.

Pemberton, R.W., 2000. Predictable risk to native plants in weed biological control. Oecologia 125, 489-494.

Ronquist, F., Huelsenbeck, J.P., 2003. MrBayes 3: Bayesian phylogenetic inference under mixed models. Bioinformatics 19, 1572-1574.

Schaffner, U., 2001. Host range testing of insects for biological weed control: How can it be 
better interpreted? Bioscience 51, 951-959.

Suckling, D.M., Sforza, R., 2014. What magnitude are observed non-target impacts from weed biocontrol? PLOS ONE 9, e84847.

Taberlet, P., Gielly, L., Pautou, G., Bouvet, J., 1991. Universal primers for amplification of three non-coding regions of chloroplast DNA. Plant. Mol. Biol. 17, 1105-1109.

Tanabe, A.S., 2011. Kakusan4 and Aminosan: two programs for comparing nonpartitioned, proportional and separate models for combined molecular phylogenetic analyses of multilocus sequence data. Mol. Ecol. Resour. 11, 914-921.

USDA/APHIS, 2016. Technical Advisory Group for Biological Control Agents of Weeds. Available at: https://www.aphis.usda.gov/aphis/ Accessed February 2016

Wahlberg, N., 2001. The phylogenetics and biochemistry of host-plant specialization in melitaeine butterflies (Lepidoptera: Nymphalidae). Evolution 55, 522-537.

Wallace, I.M., O'Sullivan, O., Higgins, D.G., Notredame, C., 2006. M-Coffee: combining multiple sequence alignment methods with T-Coffee. Nucleic Acids Res. 34, 1692-1699.

Wapshere, A.J., 1974. A strategy for evaluating the safety of organisms for biological weed control. Ann. Appl. Biol. 77, 201-211.

Wheeler, G.S., Chawner, M., Williams, D.A., 2014. Predicting the host range of Nystalea ebalea: secondary plant chemistry and host selection by a surrogate biological control agent of Schinus terebinthifolia. Biol. Control 73, 39-49.

Wheeler, G.S., Manrique, V., Overholt, W.A., Mc Kay, F., Dyer, K., 2016a. Quarantine host range testing of Pseudophilothrips ichini, A potential biological control agent of Brazilian peppertree (Schinus terebinthifolia) in North America and Hawaii. Entomol. Exp. Appl. (in press).

Wheeler, G.S., McKay, F., Vitorino, M.D., Manrique, V., Diaz, R., Overholt, W.A., $2016 \mathrm{~b}$. Biological control of the invasive weed Schinus terebinthifolia (Brazilian Peppertree): a review of the project with an update on the proposed agents. Southeastern Nat. 15 (Special Issue 8), 15-34.

Wheeler, G.S., Schaffner, U., 2013. Improved understanding of weed biological control safety and impact with chemical ecology: A review. Invasive Plant Sci. Manag. 6, 16-29. 
Wiens, J.J., Morrill, M.C., 2011. Missing data in phylogenetic analysis: reconciling results from simulations and empirical data. Syst. Biol. 60, 719-731.

Yi, T., Miller, A.J., Wen, J., 2007. Phylogeny of Rhus (Anacardiaceae) based on sequences of nuclear Nia-i3 intron and chloroplast trnC-trnD. Syst. Bot. 32, 379-391. 


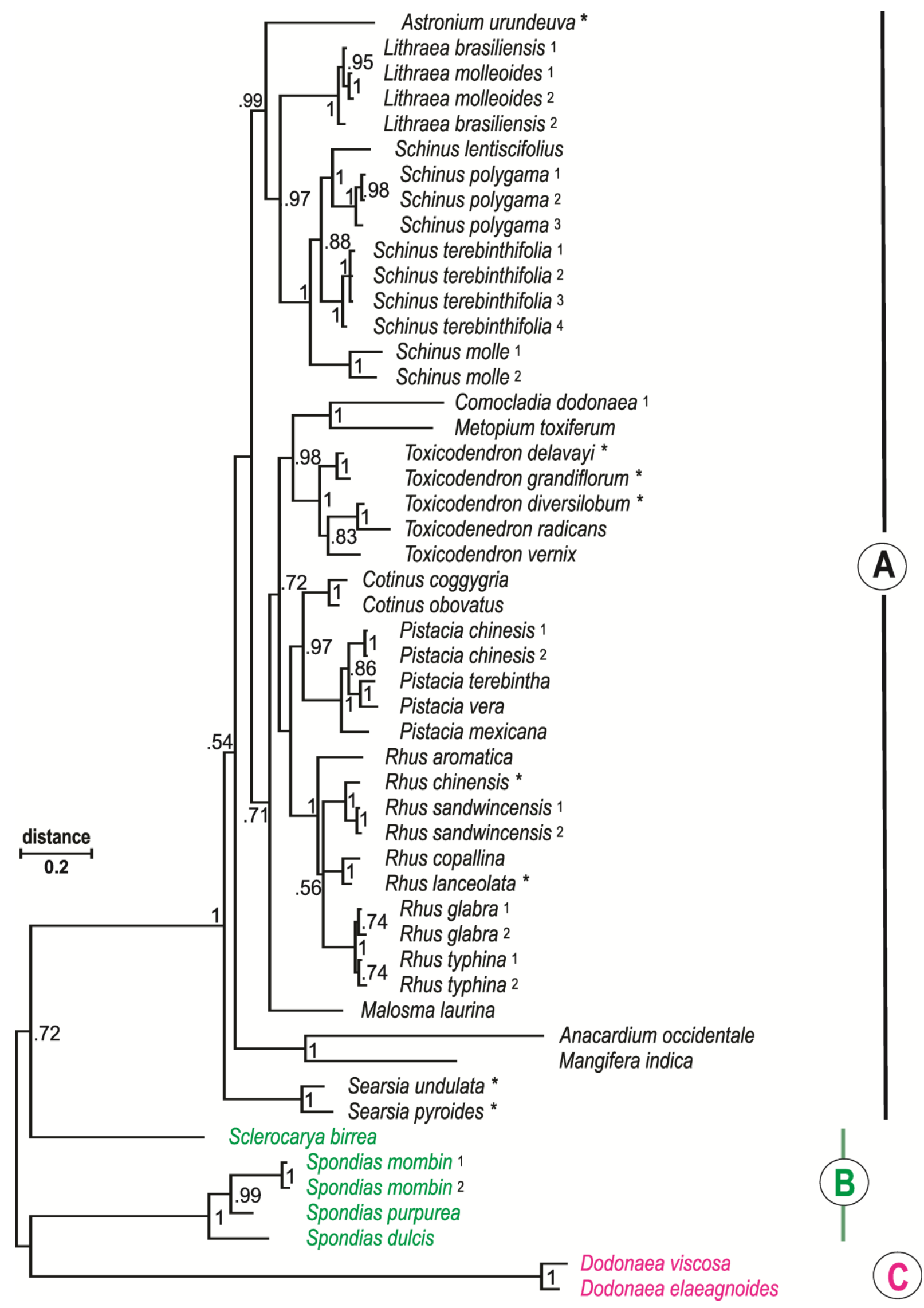




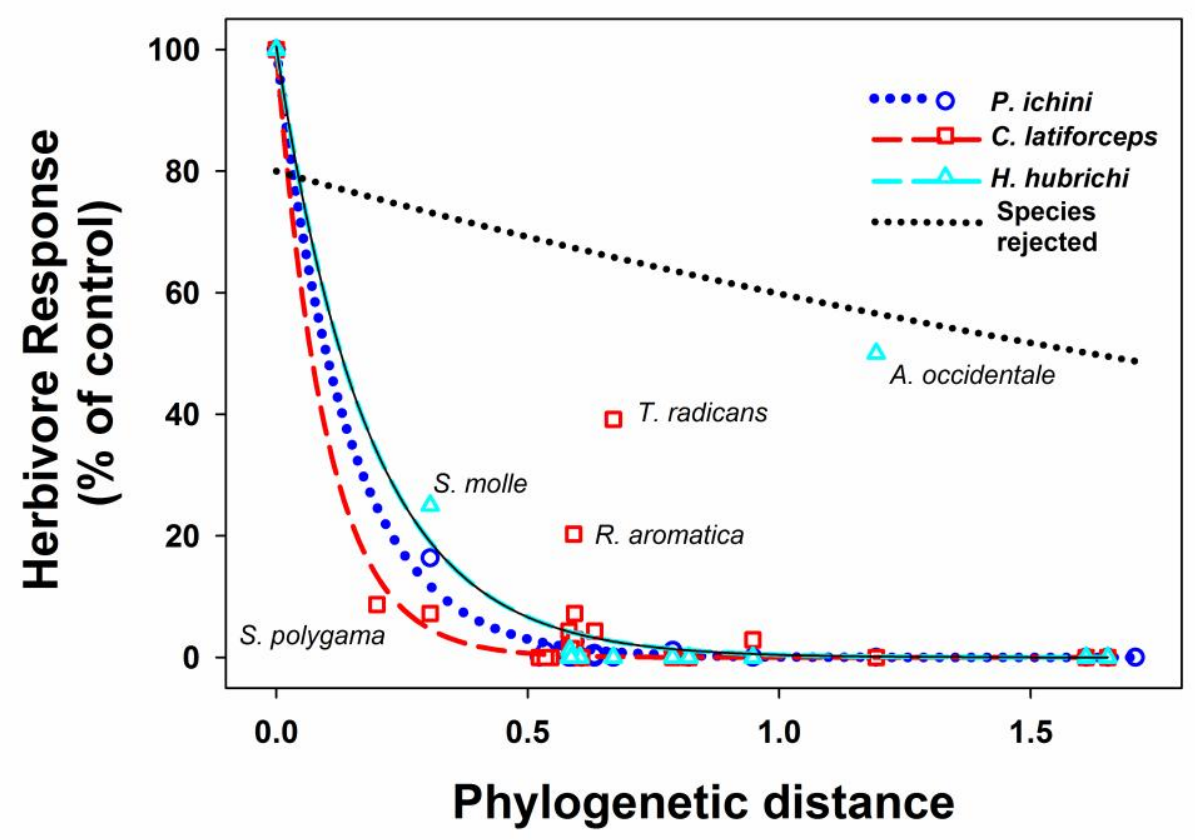


Table 1. Herbivore species that were evaluated for the biological control of Schinus terebinthifolia.

\begin{tabular}{|c|c|c|c|c|}
\hline Genus & Species & Order & Family & Source \\
\hline Calophya & latiforceps & Hemiptera & Calophyidae & (Diaz et al., 2015) \\
\hline Pseudophilothrips & ichini & Thysanoptera & Phlaeothripidae & $\begin{array}{l}\text { (Wheeler et al., } \\
\text { 2016a) }\end{array}$ \\
\hline Apocnemidophorus & pipitzi & Coleoptera & Curculionidae & TAG decision $^{1}$ \\
\hline Omolabus & piceus & Coleoptera & Curculionidae & (Wheeler et al., 2013) \\
\hline Plectrophoroides & lutra & Coleoptera & Curculionidae & (Wheeler et al., 2011) \\
\hline Paectes & longiformis & Lepidoptera & Euteliidae & $\begin{array}{l}\text { (Manrique et al., } \\
\text { 2014) }\end{array}$ \\
\hline Hymenomima & memor & Lepidoptera & Geometridae & (Broggi et al., 2016) \\
\hline Oospila & pallidaria & Lepidoptera & Geometridae & $\begin{array}{l}\text { Chawner and Wheeler } \\
\text { unpublished }\end{array}$ \\
\hline Oxydia & vesulia & Lepidoptera & Geometridae & $\begin{array}{l}\text { (Fung and Wheeler, } \\
\text { 2016) }\end{array}$ \\
\hline Prochoerodes & onustaria & Lepidoptera & Geometridae & $\begin{array}{l}\text { (Jones and Wheeler } \\
\text { unpublished) }\end{array}$ \\
\hline Eucosmophora & schinusivora & Lepidoptera & Gracillariidae & (Rendon et al., 2012) \\
\hline Leurocephala & schinusae & Lepidoptera & Gracillariidae & (Mc Kay et al., 2012) \\
\hline Tolype & medialis & Lepidoptera & Lasiocampidae & $\begin{array}{l}\text { (Wheeler } \\
\text { unpublished) }\end{array}$ \\
\hline Nystalea & ebalea & Lepidoptera & Notodontidae & (Wheeler et al., 2014) \\
\hline Tecmessa & elegans & Lepidoptera & Notodontidae & (Oleiro et al., 2011) \\
\hline Episimus & unguiculus & Lepidoptera & Tortricidae & TAG decision $^{1}$ \\
\hline Heteroperreyia & hubrichi & Hymenoptera & Pergidae & $\begin{array}{l}\text { (Hight et al., 2003; } \\
\text { Medal et al., 1999) }\end{array}$ \\
\hline
\end{tabular}

${ }^{1}$ Technical Advisory Group web site (http://www.aphis.usda.gov/). 
Table 2. Estimates of phylogenetic distances between sequences of Schinus terebinthifolia and each listed species. The average (SE) Bayesian phylogenetic distance per site compared with four S. terebinthifolia sequences are shown. Phylogenetic distance values ranged from 0.0009 to 3.038 .

\begin{tabular}{|c|c|c|c|c|c|}
\hline Family & Subfamily & Genus & Species & Mean & SE \\
\hline \multirow[t]{37}{*}{ Anacardiaceae } & Anacardioideae & & & & \\
\hline & & Schinus & lentiscifolia & 0.219 & 0.0048 \\
\hline & & & molle & 0.306 & 0.0033 \\
\hline & & & polygama & 0.200 & 0.0033 \\
\hline & & Lithrea & brasiliensis & 0.381 & 0.0033 \\
\hline & & & molleoides & 0.401 & 0.0035 \\
\hline & & Cotinus & coggygria & 0.546 & 0.0048 \\
\hline & & & obovatus & 0.523 & 0.0048 \\
\hline & & Astronium & urundeuva & 0.543 & 0.0049 \\
\hline & & Malosma & laurina & 0.535 & 0.0048 \\
\hline & & Rhus & aromatica & 0.591 & 0.0047 \\
\hline & & & chinensis & 0.582 & 0.0049 \\
\hline & & & copallina & 0.582 & 0.0049 \\
\hline & & & glabra & 0.593 & 0.0034 \\
\hline & & & lanceolata & 0.558 & 0.0048 \\
\hline & & & sandwicensis & 0.584 & 0.0034 \\
\hline & & & typhina & 0.594 & 0.0035 \\
\hline & & Toxicodendron & delavayi & 0.538 & 0.0049 \\
\hline & & & diversilobum & 0.596 & 0.0048 \\
\hline & & & grandiflorum & 0.557 & 0.0048 \\
\hline & & & radicans & 0.670 & 0.0048 \\
\hline & & & vernix & 0.586 & 0.0049 \\
\hline & & Pistacia & chinensis & 0.604 & 0.0034 \\
\hline & & & terebintha & 0.625 & 0.0048 \\
\hline & & & mexicana & 0.607 & 0.0048 \\
\hline & & & vera & 0.633 & 0.0049 \\
\hline & & Searsia & undulata & 0.636 & 0.0047 \\
\hline & & Searsia & pyroides & 0.659 & 0.0049 \\
\hline & & Metopium & toxiferum & 0.788 & 0.0049 \\
\hline & & Comocladia & dodonaea & 0.820 & 0.0047 \\
\hline & & Mangifera & indica & 0.948 & 0.0047 \\
\hline & & Anacardium & occidentale & 1.193 & 0.0047 \\
\hline & Spondioideae & & & & \\
\hline & & Sclerocarya & birrea & 1.389 & 0.0047 \\
\hline & & Spondias & dulcis & 1.653 & 0.0048 \\
\hline & & & mombin & 1.708 & 0.0033 \\
\hline & & & purpurea & 1.610 & 0.0047 \\
\hline
\end{tabular}


Sapindaceae

\begin{tabular}{llll} 
Dodonaea $\quad$ elaeagnoides & 2.474 & 0.0047 \\
& & 2.496 & 0.0048 \\
\hline
\end{tabular}

$\begin{array}{lll}\text { viscosa } & 2.496 & 0.0048\end{array}$


Table 3. Non-linear regression for herbivore relative responses that were either rejected or approved for biological control of Schinus terebinthifolia.

\begin{tabular}{|c|c|c|c|c|c|c|c|c|}
\hline \multirow{2}{*}{$\begin{array}{c}\text { Herbivore } \\
\text { species }\end{array}$} & \multirow[b]{2}{*}{$\mathrm{B}_{\mathrm{o}}$} & \multirow[b]{2}{*}{$\mathrm{B}_{1}$} & \multirow[b]{2}{*}{$\mathbf{F}$} & \multirow[b]{2}{*}{$\mathbf{P}$} & \multicolumn{2}{|c|}{$\mathrm{B}_{0}$} & \multicolumn{2}{|c|}{$B_{1}$} \\
\hline & & & & & LCI $95 \%$ & UCI 95\% & LCI 95\% & UCI $95 \%$ \\
\hline Rejected & 81.2 & 1.2 & 48.29 & $<0.0001$ & 53.2 & 109.3 & 0.5 & 1.8 \\
\hline Approved & 99.6 & 10 & 46.95 & $<0.0001$ & 77.9 & 121.4 & 2.9 & 17.16 \\
\hline
\end{tabular}

\begin{tabular}{ccccccccc}
\hline Physiological data & \multicolumn{10}{c}{} & & & & & & & \\
& & & & & & & & \\
Rejected & 84.6 & 0.2 & 119.48 & $<0.0001$ & 63.3 & 106 & -0.1 & 0.6 \\
Approved & 99.8 & 10.3 & 283.79 & $<0.0001$ & 91.4 & 108.2 & 6.4 & 14.3
\end{tabular}

Non-linear coefficients were obtained with the model: Response $\left(\%\right.$ of control) $=b o * \exp (-b 1 \mathrm{x}) ; b_{0}$ was the $y$-intercept, $b_{1}$ was the slope coefficient and $\mathrm{x}$ was $\log 10$ (distance +1$)$. 

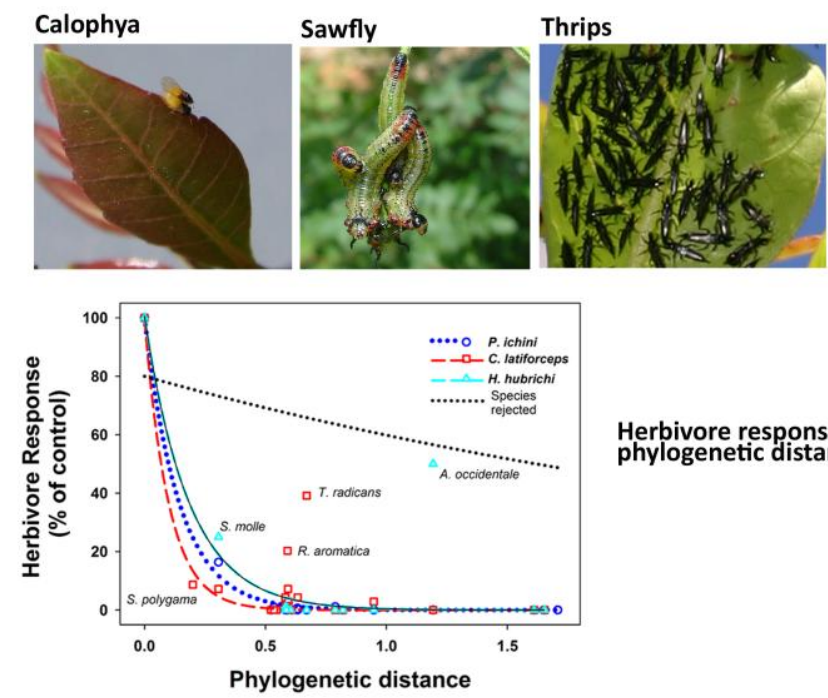

Herbivore response to phylogenetic distance 